\title{
Properties of Starch from Florido Yam (Dioscorea alata L.) ${ }^{1}$
}

\author{
J.R. Cruz-Cay and M. A. González ${ }^{2}$
}

\section{INTRODUCTION}

Yam is a popular food crop in Puerto Rico. A number of varieties are cultivated locally, but only two, Florido (D. alata) and Habanero or Guinea Blanco (D. rotundata), are grown commercially.

In spite of the agricultural importance of the yam in Puerto Rico, studies have not been made locally on the properties of its starches. Axtmayer and Cook (1) studied the chemical composition of some varieties grown in Puerto Rico, but not the properties of the starch granule. Rasper and Coursey (12) have determined the amylose content and studied the rheological properties of the starches of some West African species and varieties. Rasper (11) determined the granule size of $D$. alata. Rao and Beri $(9,10)$ described the properties of the starches of some Asiatic varieties, including $D$. alata, and Winton (13) the microscopic structure of the granule in D. alata.

Knowledge pertaining to the properties of a particular starch could be used to predict its behavior under actual cooking and cooling conditions. With such knowledge, the starch could be modified if necessary to suit product and process needs.

This publication reports research conducted on the properties of starch from the Florido yam grown under local commercial conditions.

\section{MATERIALS AND METHODS}

The starch was isolated following the method of Badenhuizen (2), using a cold 1-percent ammonium oxalate solution for extraction. The extracted starch was analyzed chemically for $\mathrm{pH}$, ash, protein, and fiber to ascertain purity. The $\mathrm{pH}$ was determined with a $\mathrm{pH}$ meter on a suspension of $10 \mathrm{~g}$ of starch, dry weight, in $20 \mathrm{ml}$ of distilled water. Ash, protein, and fiber were determined according to the methods of the A.O.A.C. (8); amylose, by the iodimetric method of Gilbert and Spragg (4); the starch solution was prepared following the method of Carrol and Cheung (3); granule size (diameter) was determined following the method of Mac Masters (6).

The rheological properties of the starch were studied in a Brabender

1 Manuscript submitted to Editorial Board September 28, 1973.

2 Assistant Food Technologist and Technical Director, respectively, Food Technology Laboratory, Agricultural Experiment Station, Mayagüez Campus, University of Puerto Rico, Río Piedras, P.R. 
Amylograph-Viscograph, Research Model, ${ }^{3}$ following the procedure outlined by Mazurs et al. (7). Concentrations of 23, 25, 26, 27.5, 28, 29, 30, 31 and $32 \mathrm{~g} / 500 \mathrm{ml}$ were used. Brabender curves were recorded for each concentration with the instrument being operated at a constant rotational ,speed of $40 \mathrm{r} / \mathrm{min}$ using a sensitivity cartridge of $700 \mathrm{~cm} / \mathrm{g}$. These curves were then replotted on rectangular coordinates where five points of significance are obtained:

A. Peak viscosity, irrespective of the temperature at which the pasting peak is attained.

B. Viscosity when the paste reaches a temperature of $93^{\circ} \mathrm{C}$.

C. Viscosity after cooking for 1 hour in the Brabender at $93^{\circ} \mathrm{C}$.

D. Viscosity when the cooked paste is cooled to $50^{\circ} \mathrm{C}$ in the Brabender.

E. Final viscosity after stirring in the Brabender for 1 hour at $50^{\circ} \mathrm{C}$.

The viscosity at each of these five points (fig. 1) was replotted against the logarithm of the starch concentration to give five curves which show the influence of concentration on the significant stages in the cooking and cooling cycles.

\section{RESULTS AND DISCUSSION}

The chemical composition of the starch on a dry weight basis was: ash, 0.12 percent; protein, 0.58 percent; fiber, 0.05 percent; and it had a $\mathrm{pH}$ of 6.80. These results indicate that the starch was pure enough for further experimental work.

The amylose content of the starch was 34 percent. This value is higher than the 21 percent amylose reported by Rasper and Coursey (12) for D. alata and other varieties grown in West Africa, and also higher than values reported for potato, corn, rice and sorghum starches (14).

The starch granule, as observed under a microscope $(400 \times)$, was oval in shape. Rings were evident. The hilum was in an eccentric position. The average diameter was $31 \mu \mathrm{m}$, higher than the $26 \mu \mathrm{m}$, reported by Rasper (11) for D. alata.

The curves obtained when the five points of significance of the Brabender curves are replotted against the logarithm of the concentration are shown in figure 1. The starch shows a moderate and progressive rise in viscosity with increasing concentration. Starch slurries can be used safely to a concentration of $27 \mathrm{~g} / 500 \mathrm{ml}$. A steep increase in viscosity occurs above that concentration.

Most starches exhibit a peak viscosity which then decreases due to the

3rade names are used in this publication solely for the purpose of providing specific information. Mention of trade names does not constitute a guarantee or warranty of the equipment by the Agricultural Experiment Station of the University of Puerto Rico or an endorsement over other equipment not mentioned. 


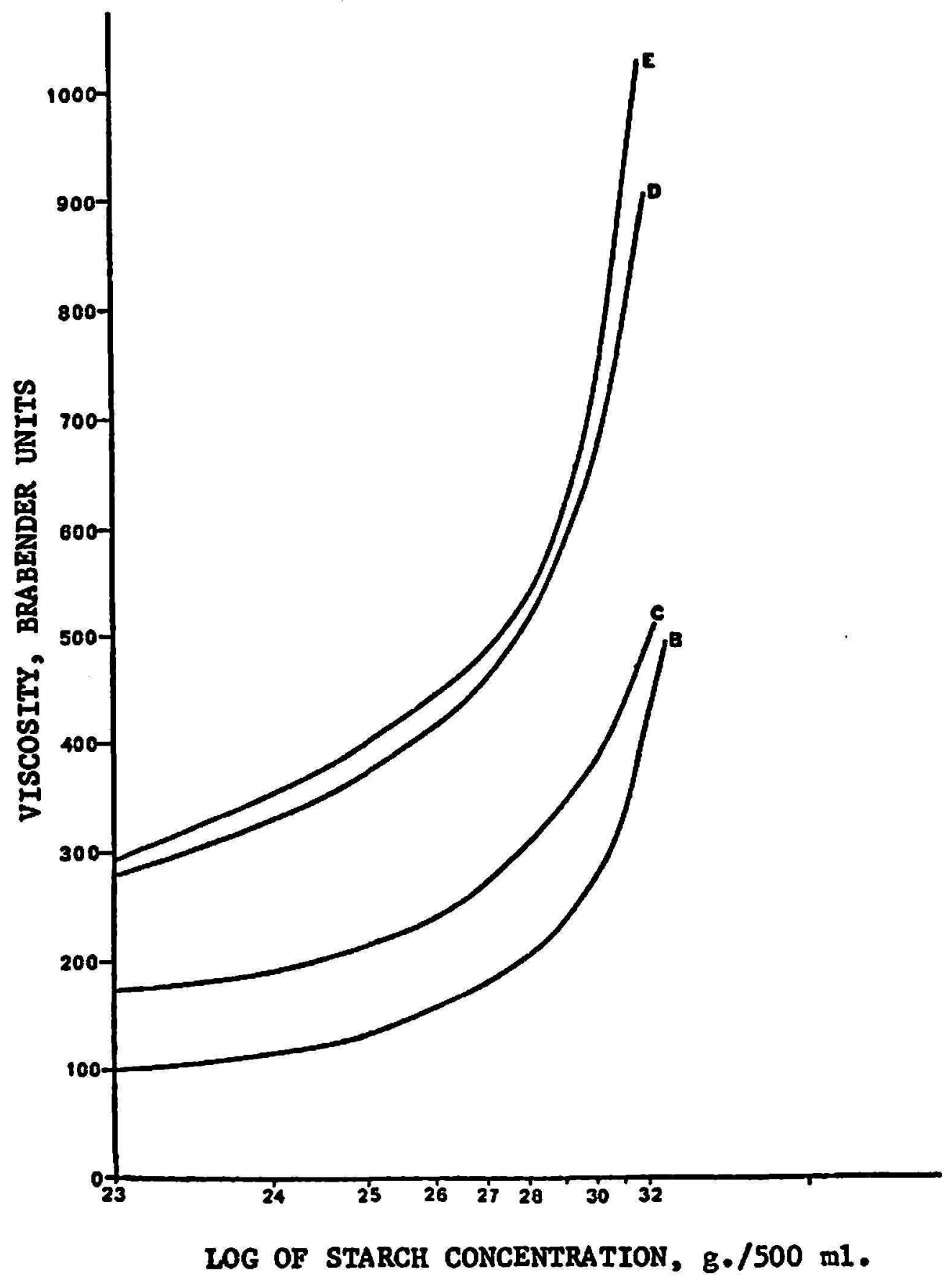

Fig. 1.-Influence of the Florido yam starch concentration on the viscosity at various stages.

progressive fragmentation and solubilization of the swollen granules. On the contrary, Florido yam starch does not exhibit such a peak viscosity as its viscosity continues to increase within the used limits of time and temperature. As stated by Mazurs et al. (7), this behavior reflects the stability of the swollen granule against mechanical disintegration. Starches which have been chemically cross-bonded with formaldehyde, epichlorohydrin or phosphate ester linkages do not show peak viscosity. Also, Florido yam 
starch does not thin down during the 1 hour cooking period at $93^{\circ} \mathrm{C}$ as shown by curves $\mathrm{B}$ and $\mathrm{C}$, figure 1 . This behavior again reflects the great stability of the swollen granule.

The viscosity also increases upon cooling to $50^{\circ} \mathrm{C}$ as shown by curve $\mathrm{D}$, figure 1. The extent of the increase in viscosity upon cooling to $50^{\circ} \mathrm{C}$ reflects the retrogradation tendency of the starch product. Of the many factors that influence retrogradation, the three most important are the concentration of amylose, the length of the amylose molecule and the state of dispersion of the linear chains (5). The amylose content is the only one of the three factors. which is known, and it is high. Thus, this high amylose content is probably responsible for the retrogradation. The viscosity also increased during the 1-hour cooking at $50^{\circ} \mathrm{C}$ but to a lesser extent, as can be seen by the relative position of curves $D$ and $E$, figure 1 .

\section{SUMMARY}

Some of the most important properties of the Florido yam (Dioscorea alata L.) starch were investigated. The starch has an amylose content of 34 percent and the oval-shaped granule is $31 \mu \mathrm{m}$ in diameter, both values being higher than previously reported in the literature.

The viscosity of the starch increased throughout the cooking and cooling cycles. The starch did not exhibit a peak viscosity, a factor which reflects the stability of the swollen granule.

\section{RESUMEN}

Se estudiaron algunas de las propiedades más importantes del almidón del ñame Florido (Dioscorea alata L.). El almidón contiene un 34 porciento de amilosa, el gránulo es de forma ovalada y tiene un dí́metro de $31 \mu \mathrm{m}$, excediendo ambos los valores informados en la literatura.

La viscosidad del amidón aumentó durante todo el proceso de cocción y enfriamiento. El almidón no exhibió un punto de viscosidad máximo, lo cual refleja la estabilidad del gránulo hinchado.

\section{LITERATURE CITED}

1. Axtmayer, J. H., and Cook, D. H., Manual de Bromatología, Publicación Núm. 186, Oficina Sanitaria Panamericana, Washington, D.C., septiembre de 1942.

2. Badenhuizen, N. P., Methods in Carbohydrate Chemistry, Vol. IV, Academic Press, New York, N.Y., and London, Eng., 14-15, 1964.

3. Carroll, B., and Cheung, H. C., Methods in Carbohydrate Chemistry, Vol. IV, Academic Press, New York, N.Y., and London, Eng., 170-71, 1964.

4. Gilbert, G. A., and Spragg, S. P., Methods in Carbohydrate Chemistry, Vol. IV, Academic Press, New York, N.Y., and London, Eng., 168-69, 1964.

5. Leach, H. W., Starch: Chemistry and Technology, Vol. 1, Academic Press, New York, N.Y., and London, Eng., 303, 1964.

6. Mac Masters, M. M., Methods in Carbohydrate Chemistry, Vol. IV, Academic Press, New York, N.Y., and London, Eng., 233-40, 1964. 
316 JOURNAL OF AGRICULTURE OF UNIVERSITY OF PUERTO RICO

7. Mazurs, E. G., Schoch, T. J., and Kite, F. E., Graphical analysis of the Brabender viscosity curves of various starches, Cereal Chem. 34 (3): 141-52, 1957.

8. Methods of Analysis of the Association of Official Agricultural Chemists, 10th ed., Washington, D.C., 1965.

9. Rao, P.S., and Beri, R. M., Tubers of Dioscorea hispida Dennst, Indian Forester 78: 146, 1952.

10. Rao, P. S., and Beri, R. M., Non-cereal foods: Tubers of Dioscorea species, Indian Forester 79: 568, 1953.

11. Rasper, V., Investigations on starches from major starch crops grown in Ghana. I. Hot paste viscosity and gel forming power, J. Sci. Fd. Agr. 20: 165-71, 1969.

12. - - and Coursey, D. G., Properties of starches of some West African yams, J. Sci. Fd. Agr. 18: 241-4, 1967.

13. Winton, A. L., and Winton, K. B., The Structure and Composition of Foods, John Wiley and Sons, Inc., New York, N.Y. Vol. 1, 1932.

14. Ziemba, J. V., Food Starches, Food Eng. 37 (10): 71-91. 1965. 